AGENDA : Analisis Gender dan Agama , Vol. 3 (1), 2021, (Juni)

ISSN Print: 2615-1502

ISSN Online: $2723-3278$

Tersedia online di

\title{
TEACHERS 'ANXIETY LEVELS IN FACING THE COVID-19 PANDEMIC VIEWED FROM GENDER ASPECTS
}

\section{Fadillatul Nisa}

MTsN 2 Pesisir Selatan, Sumatera Barat, Indonesia

E-mail: fadillatulnisa.fn@gmail.com

\begin{abstract}
This quantitative descriptive field study aims to determine the level of teachers' anxiety in facing the Covid-19 pandemic from a gender perspective. It is urgently needed to be conducted since teachers has dual roles during the Covid-19 pandemic, in which they have to be educators as well as parents who help children in online learning process. At the same time, the learning system keeps changing, lack of students' awareness in implementing health protocols, and many students who do not do school tasks are some reasons why teachers have anxiety in the pandemic Covid-19 era. The population of this study were 39 civil servant teachers at MTsN 2 Pesisir Selatan consists of 30 female teachers and 9 male teachers. Samples were taken by using total sampling technique. Data were collected through a questionnaire developed from the Hamilton Rating Scale for Anxiety (HRS-A). The data analysis technique used is descriptive statistical analysis. The results showed that female teachers had high anxiety level with a percentage of $62.76 \%$. Meanwhile, male teachers had medium anxiety level with a percentage of $57.82 \%$. It reflects that female teachers had higher anxiety level than male teachers by a difference of $4.94 \%$.
\end{abstract}

Keywords: Anxiety Disorders, Teachers' Anxiety Levels, Pandemic Covid-19 Era

\section{PENDAHULUAN:}

Data Kementerian Kesehatan Indonesia menyatakan bahwa hingga 16 Oktober 2020, jumlah kasus positif virus covid-19 adalah sebanyak 353.461 orang. Angka ini bertambah sebanyak 4.301 kasus dari hari sebelumnya (kemkes.go.id/, 16/10/2020). Peningkatan kasus positif yang berkelanjutan memberi tekanan tersendiri pada guru yang wilayahnya sudah menggunakan proses pembelajaran sistem tatap muka, MTsN 2 Pesisir Selatan salah satunya. Adanya rasa cemas jika seandainya terpapar virus covid-19 menimbulkan perasaan tidak nyaman dalam melaksanakan aktivitas sehari-hari. 
Guru merasa cemas saat melaksanakan tugasnya dalam mencerdaskan anak bangsa. Alhasil, dikhawatirkan proses pembelajaran peserta didik belum dapat terlaksana secara efektif dan efisien (Sumarlin, wawancara, 17 Oktober 2020).

Secara etimologis, kata kecemasan berasal dari akar kata cemas yang diartikan sebagai tidak tenteram hati (karena khawatir, takut) dan gelisah. Sedangkan kata kecemasan dimaknai sebagai: 1) perihal cemas; 2) terlampau cemas

(https://kbbi.web.id, 16/10/2020). Secara terminologis, kecemasan dapat dipahami sebagai suatu keadaan aprehensi atau keadaan khawatir yang mengeluhkan bahwa sesuatu yang buruk akan segera terjadi (Nevid, 2005: 163). Sesuatu yang buruk itu akan dikenali sebagai peristiwa yang berada di luar jangkauan kenyaman pada sistem konstruk seseorang (Kelly dalam Cervone, 2012: 195). Apabila kecemasan ini hadir dalam intensitas yang tinggi dapat mengganggu ritme kehidupan yang berujung pada gangguan fisik dan psikis manusia (Gustiar, 2010:9; Cutler, 2004:304).

Gejala gangguan kecemasan hadir dalam bentuk gejala fisik dan mental (Sundari (2004:62). Gejala tersebut dijabarkan secara lebih rinci oleh Rochman, (2010:103). Ia mengemukakan beberapa gejala-gejala dari kecemasan, yaitu: 1) hampir setiap kejadian menimbulkan rasa takut dan cemas. 2) Adanya emosi-emosi yang kuat dan sangat tidak stabil; 3) emosi tersebut diikuti oleh bermacam-macam fantasi, delusi, ilusi, dan delusion of persecution (delusi yang dikejar-kejar); 4) Sering merasa mual dan muntahmuntah, badan terasa sangat lelah, banyak berkeringat, gemetar, dan seringkali menderita diare; 5) Muncul ketegangan dan ketakutan yang kronis yang menyebabkan tekanan jantung menjadi sangat cepat atau tekanan darah tinggi.

Menariknya, berdasarkan observasi yang penulis lakukan di MTsN 2 Pesisir Selatan terlihat bahwa keluhan ini umumnya lebih banyak dikeluhkan oleh guru perempuan. Sementara itu, guru laki-laki terlihat lebih santai dalam menghadapi situasi dan kondisi terkini. Meski terlihat santai, belum bisa dipastikan bahwa guru laki-laki tidak mengalami masalah kecemasan akibat pandemi covid-19. Oleh sebab itu, perlu dilakukan pengukuran lebih lanjut tentang tingkat kecemasan guru di era pandemi. Pengukuran ini bertujuan untuk mengungkap tingkat kecemasan guru agar tindakan preventif dapat dilakukan oleh pihak terkait. Hal ini dikarenakan guru dengan kecemasan yang berlebihan akan gagal mengetahui terlebih dahulu bahayanya dan mengambil tindakan pencegahan yang mencukupi (Ramaiah, 2005:9).

\section{HASIL DAN PEMBAHASAN:}

\section{Tingkat Kecemasan Guru Dalam} Menghadapi Pandemi Covid-19 berbasis Gender

Setelah dilakukan pengolahan data hasil penelitian dengan bantuan program SPSS for Windows versi 20.0, maka didapatkan gambaran bahwa tingkat kecemasan guru dalam menghadapi pandemi covid-19 di MTsN 2 Pesisir Selatan secara keseluruhan berada pada kategori "tinggi", yaitu sebesar $61.62 \%$ dengan sebaran sebagai berikut: 
Tabel 1

Tingkat Kecemasan Guru dalam Menghadapi Pandemi Covid-19

\begin{tabular}{|l|c|c|}
\hline \multicolumn{1}{|c|}{ Kategori } & Frekuensi & Persen \% \\
\hline Sangat Rendah & 1 & 2.6 \\
\hline Rendah & 19 & 48.7 \\
\hline Sedang & 4 & 10.3 \\
\hline Tinggi & 4 & 10.3 \\
\hline Sangat tinggi & 11 & 28.2 \\
\hline
\end{tabular}

Tabel di atas menunjukkan bahwa sebanyak $1(2.6 \%)$ responden memiliki tingkat kecemasan "sangat rendah". Sebanyak 19 (48.7\%) responden memiliki tingkat kecemasan "rendah". Sebanyak 4 (10.3\%) responden memiliki tingkat kecemasan "sedang". Sebanyak 4 (10.3\%) responden memiliki tingkat kecemasan "tinggi" dan sebanyak $11(28.2 \%)$ responden memiliki tingkat kecemasan "sangat tinggi". Tabel di atas juga memperlihatkan bahwa mayoritas responden memiliki tingkat kecemasan kategori rendah sebesar $48.7 \%$. Lalu urutan berikutnya diikuti oleh kategori tinggi sebesar $28.2 \%$, kategori tinggi sebesar $10.3 \%$, kategori sedang sebesar $10.3 \%$ dan kategori sangat rendah sebesar $2.6 \%$.

Data di atas diperkuat oleh hasil pengolahan dengan bantuan program SPSS for Windows versi 20.0 yang menunjukkan bahwa mean empiris lebih tinggi dari mean teoritis. Artinya, secara umum sampel penelitian memiliki kecenderungan tingkat kecemasan menghadapi pandemi covid-19 pada kisaran rendah hingga sedang. Untuk lebih jelasnya dapat dilihat pada tabel berikut:

Tabel 2.

Perbandingan Statistik Deskriptif Empiris dan Teoritis Kecemasan Guru dalam Menghadapi Pandemi Covid-19

\begin{tabular}{|c|c|c|c|c|c|}
\hline & N & रัแய & Kawn & Nesul & $8 D$ \\
\hline smpir:a & $\because ;$ & 14: & Ấ & i? & דו וּי \\
\hline F_tilis: & $\vdots$ & $5:$ & 30 & 270 & viin \\
\hline
\end{tabular}

Tabel di atas memperlihatkan bahwa secara empiris, data memiliki jumlah (N) sebesar 39, skor minimum sebesar 142, skor maksimum sebesar 406, nilai rata-rata (mean) sebesar 277.3 dan standar deviasi sebesar 91.17. Sedangkan secara teoritis, data memiliki jumlah $(\mathrm{N})$ sebesar 39, skor minimum sebesar 90, skor maksimum sebesar 450, nilai rata-rata (mean) sebesar 270 dan standar deviasi sebesar 60. Terlihat bahwa mean empiris lebih tinggi dari mean teoritis, sehingga dapat dikatakan bahwa sebaran tingkat kecemasan guru cenderung berada pada kategori sedang hingga rendah.

Jika dianalisis dari aspek gender responden, guru perempuan memiliki tingkat kecemasan yang berada pada kategori "tinggi" sebesar $62.76 \%$. Sedangkan guru laki-laki memiliki tingkat kecemasan yang berada pada kategori "sedang" dengan persentase sebesar $57.82 \%$. Persentase yang ada menunjukkan bahwa guru perempuan memiliki tingkat kecemasan dalam menghadapi pandemi covid-19 satu tingkat lebih tinggi dari guru laki-laki dengan selisih sebesar $4.94 \%$. Perbandingan tingkat kecemasan antara guru perempuan dan laki-laki dapat dilihat pada tabel di bawah ini:

Tabel 3

Perbandingan Tingkat Kecemasan Guru dalam Menghadapi Pandemi

Covid-19 berdasarkan gender

\begin{tabular}{|c|c|c|c|c|}
\hline \multirow[t]{2}{*}{ Ratanmel } & \multicolumn{2}{|c|}{ f.тाแ Pe' } & \multicolumn{2}{|c|}{ C.mाI 1.nL-Fak } \\
\hline & Fיזה & Prysral का & 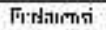 & Pिד: \\
\hline 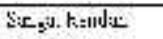 & - & UI & 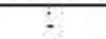 & $\because::$ \\
\hline $3 t \cdots-h$ & $\Leftrightarrow$ & 5i & 1 & 111 \\
\hline يو & 1 & 13.3 & : & : \\
\hline$\gamma$ & 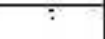 & 67 & ? & $\pi$ \\
\hline 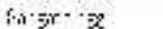 & ; & in & ; & $\because ;$ \\
\hline
\end{tabular}


Data pada tabel di atas menunjukkan bahwa guru perempuan memiliki tingkat kecemasan kategori "sangat rendah" sebesar 0\%, kategori "rendah" sebesar 50\%, kategori "sedang" sebesar 13.3\%, kategori "tinggi" sebesar $6.7 \%$ dan kategori "sangat tinggi" sebesar $30 \%$. Sedangkan guru laki-laki memiliki tingkat kecemasan kategori "sangat rendah" sebesar $11.1 \%$, kategori "rendah" sebesar 44.4\%, kategori "sedang" sebesar 0\%, kategori "tinggi" sebesar $22.2 \%$ dan kategori "sangat tinggi" sebesar 22.2\%. Mayoritas tingkat kecemasan guru perempuan dan laki-laki berada pada kategori yang sama, yaitu kategori "rendah".

\section{Tingkat Kecemasan Guru Dalam Menghadapi Pandemi Covid-19 berbasis Gender pada Tiap Indikator Kecemasan}

Kecemasan dalam menghadapi pandemi covid-19 pada penelitian ini diukur melalui 14 gejala (indikator). Untuk mengetahui tingkat kecemasan guru laki-laki dan guru perempuan pada masing-masing indikator dilakukan pengelompokan skor berdasarkan gender. Setelah itu skor masing-masing gender dipersentasekan kemudian dikonsultasikan kepada norma yang telah ditetapkan. Hasil pengolahan data tingkat kecemasan guru dalam menghadapi pandemi covid-19 berbasis gender pada tiap indikator kecemasan dapat dilihat pada tabel berikut:

Tabel 4.

Perbandingan Persentase Kecemasan

Guru dalam Menghadapi Pandemi

Covid-19 berdasarkan gender pada

Tiap Indikator Kecemasan

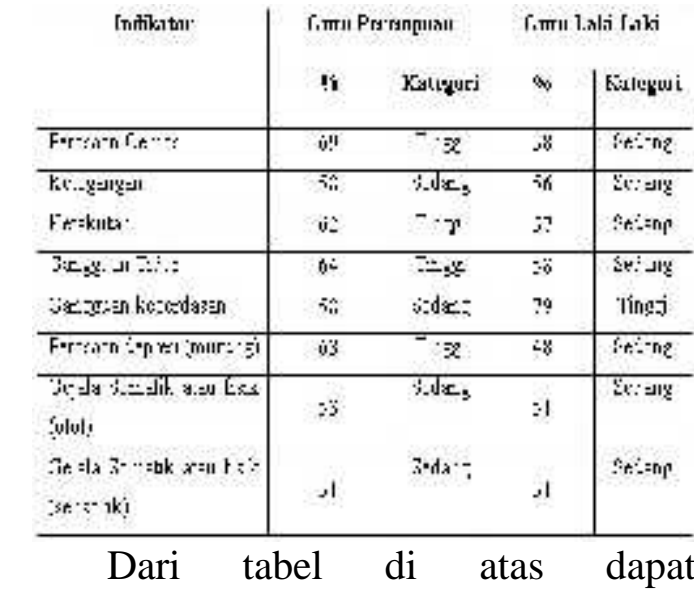
dideskripsikan bahwa tingkat kecemasan guru perempuan pada indikator perasaan cemas berada pada kategori "tinggi" dengan persentase sebesar $69 \%$ Sedangkan tingkat kecemasan guru laki-laki pada indikator ini berada pada kategori "sedang" dengan persentase sebesar $58 \%$. Data ini memiliki selisih sebesar $11 \%$. Artinya, gejala perasaan cemas saat mendengar, membaca, membicarakan atau menyaksikan segala sesuatu yang terkait dengan covid-19 yang meliputi cemas, firasat buruk, takut akan pikiran sendiri dan mudah mudah tersinggung lebih banyak dialami oleh guru perempuan daripada guru laki-laki.

Sedangkan pada indikator ketegangan, guru perempuan berada pada kategori "sedang" dengan persentase sebesar 58\% dan guru lakilaki juga berada pada kategori "sedang" dengan persentase sebesar $56 \%$. Guru perempuan dan guru lakilaki sama-sama berada pada kategori sedang dan hanya memiliki selisih sebesar 2\%. Artinya, gejala ketegangan saat mendengar, membaca, membicarakan atau menyaksikan segala sesuatu yang terkait dengan covid-19 yang meliputi merasa tegang, lesu, tidak bisa istirahat tenang, mudah terkejut, mudah menangis, gemetar dan 
gelisah dialami oleh guru perempuan mau pun guru laki-laki.

Pada indikator ketakutan dalam menghadapi pandemi covid-19, guru perempuan berada pada kategori "tinggi" dengan persentase sebesar $62 \%$ dan guru laki-laki juga berada pada kategori "sedang" dengan persentase sebesar 57\%. Guru perempuan dan guru laki-laki memiliki selisih sebesar 5\%. Artinya, gejala ketakutan yang muncul saat mendengar, membaca, membicarakan atau menyaksikan segala sesuatu yang terkait dengan covid-19 yang meliputi takut gelap, takut pada orang asing, takut ditinggal sendiri, takut pada binatang besar, takut pada keramaian lalu lintas dan takut pada kerumunan orang banyak lebih banyak dialami oleh guru perempuan daripada guru laki-laki.

Sedangkan indikator gangguan tidur dengan gejala sukar tidur, sering terbangun pada malam hari, tidur tidak nyenyak, bangun dengan lesu, banyak mengalami mimpi, bermimpi buruk dan mimpi menakutkan lebih sering dialami oleh guru perempuan daripada guru laki-laki. Data pada tabel menunjukkan bahwa guru perempuan mengalami gejala gangguan tidur kategori "tinggi" dengan persentase sebesar $64 \%$. Sedangkan guru laki-laki mengalami gejala gangguan tidur kategori "sedang" dengan persentase sebesar 58\%. Artinya, terdapat selisih sebesar $6 \%$ yang menjadikan guru perempuan lebih banyak mengalami gejala gangguan tidur akibat pandemi covid-19.

Indikator selanjutnya adalah gangguan kecerdasan. Guru laki-laki mengalami gejala sukar konsetrasi, penurunan daya ingat hingga daya ingat buruk $21 \%$ lebih tinggi dari guru perempuan. Guru laki-laki memiliki gejala gangguan kecerdasan saat mendengar, membaca, membicarakan atau menyaksikan segala sesuatu yang terkait dengan covid-19 kategori "tinggi" dengan persentase sebesar $79 \%$. Sedangkan guru permpuan berada pada kategori "sedang" dengan persentase sebesar 58\%.

Pada indikator perasaan depresi (murung), guru perempuan berada pada kategori "tinggi" dengan persentase sebesar $63 \%$ dan guru laki-laki berada pada kategori sedang dengan persentase $48 \%$. Artinya, terdapat selisih sebesar $15 \%$ antara guru perempuan dan guru laki-laki. Selisih ini menjadikan guru perempuan lebih banyak mengalami perasaan depresi yang ditandai oleh hilangnya minat, berkurangnya kesenangan pada hobi, sedih, perasaan berubah-ubah sepanjang hari dan bangun dini hari akibat mendengar, membaca, membicarakan atau menyaksikan segala sesuatu yang terkait dengan covid-19.

Gejala somatik fisik (otot) yang ditandai oleh sakit dan nyeri otot, kaku, kedutan otot, gigi gemerutuk dan suara tidak stabil guru perempuan berada pada kategori "sedang" dengan persentase sebesar 53\%. Guru laki-laki, pada indikator ini, berada pada kategori "sedang" dengan persentase sebesar 51\%. Meski sama-sama berada pada kategori sedang, persentase gangguan somatik otot guru perempuan lebih tinggi sebesar $2 \%$ dari guru laki-laki. Sehingga dapat dikatakan bahwa gejala gangguan somatik (otot) lebih banyak dialami oleh guru perempuan.

Sedangkan pada indikator somatik atau fisik (sensorik) dengan gejala telinga berdenging, penglihatan kabur, muka merah atau pucat, merasa lemas 
dan perasaan ditusuk-tusuk sama-sama dialami oleh guru perempuan dan guru laki-laki. Baik guru perempuan atau guru laki-laki mengalami gejala sensoris kategori "sedang" dengan persentase sebesar 51\%. Artinya, terdapat tidak terdapat selisih antara gejala sensoris guru laki-laki dan perempuan. Sehingga bisa dikatakan bahwa keduanya sama-sama mengalami gejala gangguan sensoris akibat pandemi covid-19 pada kategori sedang.

Sedangkan indikator gangguan kardiovaskuler dengan gejala denyut jantung cepat, berdebar-debar, nyeri di dada, denyut nadi mengeras, rasa lesu atau lemas seperti mau pingsan atau detak jantung berhenti sekejap lebih sering dialami oleh guru perempuan daripada guru laki-laki. Data pada tabel menunjukkan bahwa guru perempuan mengalami gejala gangguan kardiovaskuler kategori "tinggi" dengan persentase sebesar $62 \%$. Sedangkan guru laki-laki mengalami gejala gangguan tidur kategori "sedang" dengan persentase sebesar 53\%. Artinya, terdapat selisih sebesar 9\% yang menjadikan guru perempuan lebih banyak mengalami gejala gangguan kardiovaskuler akibat pandemi covid-19.

Gejala rasa tertekan atau sempit di dada, perasaan tercekik, sering menarik nafas dan nafas pendek atau sesak yang menjadi penanda indikator gangguan respiratory (pernafasan) guru perempuan dan guru laki-laki samasama berada pada kategori "sedang". Bedanya ada pada persentase, guru perempuan memiliki persentase sebesar $51 \%$ dan guru laki-laki memiliki persentase sebesar 53\%. Persentase yang ada hanya menujukkan selisih sebesar $2 \%$. Artinya gejala gangguan pernafasan sama-sama muncul pada guru laki-laki dan guru perempuan dengan kategori sedang.

Pada indikator gangguan gastrointestinal (pencernaan), guru laki-laki mengalami gejala sulit menelan, perut melilit, gangguan pencernaan, nyeri sebelum dan sesudah makan, perasaan terbakar di perut, kembung, mual, muntah, BAB lembek, konstipasi hingga kehilangan berat badan 14\% lebih tinggi dari guru perempuan. Guru laki-laki memiliki gejala gangguan pencernaan saat mendengar, membaca, membicarakan atau menyaksikan segala sesuatu yang terkait dengan covid-19 kategori "tinggi" dengan persentase sebesar $75 \%$. Sedangkan guru perempuan juga berada pada kategori "tinggi" namun dengan persentase yang lebih rendah yaitu sebesar $61 \%$.

Gejala gangguan urogenital (perkemihan dan kelamin) yang ditandai oleh sering buang air kecil, tidak dapat menahan air seni, tidak datang bualan, darah haid berlebihan, darah haid amat sedikit, masa haid berkepanjangan, masa haid pendek, haid beberapa kali dalam sebulan (bagi guru perempuan) dan menjadi dingin (frigid), ejakulasi dini, ereksi melemah, ereksi hilang dan impotensi (bagi guru laki-laki) lebih sering dialami oleh guru perempuan yang berada pada kategori "tinggi" dengan persentase sebesar 67\%. Guru laki-laki, pada indikator ini, berada pada kategori "sedang" dengan persentase sebesar 53\%. Data ini mengantarkan pada pemahaman bahwa guru perempuan lebih banyak mengalami gejala urogenital dibandingkan guru laki-laki.

Sedangkan pada gejala autonom yang ditandai oleh mulut kering, muka merah, mudah berkeringat, kepala 
pusing, kepala terasa berat, kepala terasa sakit dan bulu-bulu berdiri saat mendengar, membaca, membicarakan atau menyaksikan segala sesuatu yang terkait dengan covid-19 guru laki-laki dan guru perempuan sama-sama berada pada kategori "tinggi". Guru perempuan memiliki persentase sebesar $70 \%$ dan guru laki-laki sebesar $64 \%$.

Selisih antara guru laki-laki dan guru perempuan adalah sebesar $6 \%$. Artinya, guru perempuan mengalami gejala autonom $6 \%$ lebih banyak daripada guru laki-laki.

Gejala gangguan tingkah laku yang ditandai oleh perasaan gelisah, tidak tenang, jari gemetar, kerut kening, muka tegang, otot tegang (mengeras), nafas pendek dan cepat serta muka memerah saat mendengar, membaca, membicarakan atau menyaksikan segala sesuatu yang terkait dengan covid-19 dialami 18\% lebih banyak oleh guru perempuan. Guru perempuan memiliki gejala gangguan tingkah laku kategori "tinggi" dengan persentase sebesar $76 \%$. Sedangkan guru laki-laki berada pada kategori "sedang" dengan persentase sebesar 58\%

Responden pada penelitian ini terdiri dari 9 orang guru laki-laki dan 30 orang guru perempuan. Hasil penelitian menunjukkan bahwa dari secara keseluruhan, tingkat kecemasan guru dalam menghadapi pandemi covid-19 berada pada klasifikasi tinggi dengan persentase sebesar $61.62 \%$. Jika ditinjau dari aspek gender responden, guru perempuan memiliki tingkat kecemasan yang berada pada kategori "tinggi" sebesar $62.76 \%$. Sedangkan guru laki-laki memiliki tingkat kecemasan yang berada pada kategori "sedang" dengan persentase sebesar $57.82 \%$. Persentase yang ada menunjukkan bahwa guru perempuan memiliki tingkat kecemasan dalam menghadapi pandemi covid-19 satu tingkat lebih tinggi dari guru laki-laki dengan selisih sebesar $4.94 \%$.

Bentuk kecemasan antara guru laki-laki dan perempuan pun berbeda. Penelitian ini menemukan bahwa guru perempuan mengalami perasaan cemas, ketegangan, ketakutan, gangguan tidur, perasaan depresi (murung), gangguan otot, gangguan sensoris, gangguan kardiovaskuler, gangguan urogenital, gangguan autonom dan gejala tingkah laku lebih banyak (sering) jika dibandingkan dengan guru laki-laki. Sedangkan guru laki-laki lebih sering merasakan gejala gangguan kecerdasan, gangguan pernafasan dan gangguan pencernaan. Baik guru lakilaki dan perempuan sama-sama merasakan gejala sensorik saat mendengar, membaca, membicarakan atau menyaksikan segala sesuatu yang terkait dengan covid-19.

Namun, temuan dalam penelitian ini tidak sejalan dengan penelitian yang dilakukan oleh Vikawati, dkk (2021: 121-126) yang menyatakan bahwa tidak ditemukan hubungan antara kecemasan dalam menghadapi pandemi covid-19 dengan jenis kelamin. Responden dalam penelitian ini dominan adalah wanita. Dua sampel wanita dari penelitian mengalami kecemasan ringan-sedang dan dua dari keseluruhan sampel laki-laki juga mengalami kecemasan ringan sedang.

Meski demikian, cukup banyak penelitian yang membuktikan bahwa perempuan memiliki tingkat kecemasan yang lebih tinggi dari lakilaki dalam menghadapi pandemi covid19. Penelitian yang dilakukan oleh tim LPPM Universitas Nahdlatul Ulama Al Ghazali Cilacap, mengungkap bahwa 
tingkat kecemasan perempuan dalam menghadapi pandemi covid-19 lebih tinggi sebesar $38 \%$ dari laki-laki dengan persentase sebesar $31 \%$ bagi laki-laki dan $69 \%$ perempuan (LPPM UNUGHA Cilacap, 2020: 15).

Hasil tersebut juga sejalan dengan temuan penelitian Martaria Rizky Rinaldi dan Reny Yuniasanti (2020:143-144) yang mengatakan bahwa berdasarkan uji $\mathrm{t}$ didapatkan nilai $\mathrm{t}=-2,485$ dengan $\mathrm{p}=0,013(\mathrm{p}<$ $0,05)$, artinya, terdapat perbedaan yang signifikan antara kecemasan laki-laki dan kecemasan pada perempuan. Ratarata kecemasan perempuan yaitu 18,4401 sedangkan rata-rata kecemasan laki-laki yaitu 16,2207 yang berarti bahwa kecemasan perempuan lebih tinggi daripada laki-laki.

\section{KESIMPULAN:}

Hasil pengolahan angket menunjukkan bahwa secara keseluruhan, tingkat kecemasan guru dalam menghadapi pandemi covid-19 berada pada kategori "tinggi", yaitu sebesar $61.62 \%$. Sedangkan dari sudut pandang gender, guru perempuan memiliki tingkat kecemasan yang berada pada kategori "tinggi" dengan persentase sebesar $62.76 \%$. Sedangkan guru laki-laki memiliki tingkat kecemasan yang berada pada kategori "sedang" dengan persentase sebesar $57.82 \%$. Persentase yang ada menunjukkan bahwa guru perempuan memiliki tingkat kecemasan dalam menghadapi pandemi covid-19 satu tingkat lebih tinggi dari guru laki-laki dengan selisih sebesar $4.94 \%$. Sedangkan jika ditinjau dari 14 indikator yang digunakan untuk mengukur tingkat kecemasan guru dalam menghadapi pandemi covid-19, Guru laki-laki dan guru perempuan memiliki persentase yang sama pada 1 dari 14 indikator kecemasan. Guru perempuan memiliki persensetase yang lebih tinggi dari guru laki-laki pada 11 dari 14 indikator kecemasan. Sedangkan guru laki-laki memiliki persentase yang lebih tinggi pada 4 indikator kecemasan dari guru perempuan.

\section{REFERENSI:}

Cervone, D., dan Lawrence A. P. 2012. Kepribadian: Teori dan Penelitian. Jakarta: Salemba Humanika

Cutler, Howard C. 2004. Seni Hidup Bahagia. (Alih Bahasa: Alex Tri KantjonoWidodo). Jakarta: Gramedia Pustaka Utama

Ekawati, Nura Viky., dkk. 2021. Tidak Didapatkan Kecemasan Pada Petugas Kesehatan dalam Menghadapi Pandemi Covid19. Jurnal Syifa' MEDIKA, Vol 11 (No.2), Maret 2021, 116-125

Kholil Lur Rochman. 2010. Kesehatan Mental. Purwokerto: Fajar Media Press

LPPM UNUGHA. 2020. Kajian Jenis Kecemasan Masyarakat Cilacap dalam Menghadapi Pandemi Covid 19. Cilacap: Universitas Nahdlatul Ulama Al Ghazali

Rinaldi, Martaria Rizky \& Reny Yuniasanti. 2020. Kecemasan Pada Masyarakat Saat Masa Pandemi Covid-19 di Indonesia dalam buku "Covid19 dalam Ragam Tinjauan Perspektif'. Yogyakarta: MBridge Press

Nevid, Jeffrey S, dkk. 2005. Psikologi Abnormal edisi kelima Jilid 1. Jakarta: Erlangga 
Ramaiah, Savitri. 2005. Kecemasan Bagaimana Mengatasi

Penyebabnya. Jakarta: Pustaka Populer Obor Rumini, Sri \& Siti Sundari. 2004.

Perkembangan Anak dan Remaja. Jakarta: PT Rineka Cipta

Semiun, Yustinus. 2006. Kesehatan Mental 3. Yogyakarta: Penerbit Kanisius
Kementerian Kesehatan RI. Data Covid-19 per 16 Oktober 2020. Tersedia di https://infeksiemerging.kemke s.go.id/, diakses tanggal 16 Oktober 2020

Kamus Besar Bahasa Indonesia. Arti Kata Kecemasan. https://kbbi.web.id, diakses tanggal 16 Oktober 2020 